\title{
Dried salted anchovy different processing methods: drying kinetics and modelling
}

\author{
Agustini, T.W., "Fahmi, A.S. and Riyadi, P.H. \\ Department of Fisheries Product Technology, Faculty of Fisheries and Marine Science, Universitas \\ Diponegoro, Semarang, Central Java 50275, Indonesia
}

\begin{abstract}
Article history:
Received: 8 February 2021

Received in revised form: 22

March 2021

Accepted: 25 March 2021

Available Online: 28 July

2021
\end{abstract}

Keywords:

Dried salted anchovy,

Drying kinetics,

Mathematic model

DOI:

https://doi.org/10.26656/fr.2017.5(S3).011

\begin{abstract}
Dried salted anchovy is processed with a combination of the salting and drying processes. Methods of salting and drying will determine the characteristics of the end product. The process of salting can be done by soaking (S) or boiling (B) in brine and drying can be done by mechanical drying (MD) or electric oven (OD). This study is aimed to determine the drying kinetics and mathematical models of dried salted anchovy processed with boiled salting and drying in the mechanical dryer (BMD), soaked salting and drying in the mechanical dryer (SMD) and boiled salting and drying in the oven (BOD). In the soaking treatment, fresh anchovy was soaked in $5 \%$ brine for 30 mins, while in boiling treatment, anchovy boiled in $5 \%$ brine for 10 mins. After the salting process was done, the anchovy was dried at $40^{\circ} \mathrm{C}$ for $3 \mathrm{hrs}$. The result has shown that BMD gives the highest drying constant. The page model is more suitable than other mathematical models because it has the highest $\mathrm{R}^{2}$ and the lowest SEE (Standard Error Estimates) value. The result of the effective diffusivity of BMD, SMD and BOD are $1.28067 \times 10^{-10}, 2.46685 \times 10^{-10}$, $1.80245 \times 10^{-10}$. This research will contribute to the improvement of the drying and salting method to achieve a better quality of dried salted anchovies.
\end{abstract}

\section{Introduction}

Dried salted anchovy is one of the most popular fisheries products in Indonesia. It is a favourite to most Indonesian from various societies. The nutritional content of dried salted anchovies includes $16.67 \%$ moisture, $62.77 \%$ protein, $15.454 \%$ lipid, and $3.63 \%$ ash (Kumar et al., 2017). Anchovies are rich in omega-3, iron, and calcium. Small quantities are sold fresh at the fish market and usually sold in salt (Siriskar et al., 2013). Salting as a pre-treatment enhances the product's capability to dry and reduce the water activity of the product within a shorter time, allowing a longer shelf life and changing the sensorial quality of food (Chabbouh et al., 2011).

Salting is one of the oldest traditional and commonly used processing techniques for fish preservation worldwide because of its low production cost and the simplicity of the process (Martínez-Alvarez and GómezGuillén, 2013). Salt is effective as a fish preservative because salt can reduce the fish muscle's water activity. Consequently, bacterial growth and enzymatic spoilage are inhibited. On the other hand, the current demand for salted fish is driven by sensorial alteration purposes rather than preservation (Mujaffar and Sankat, 2005). Besides, drying and salting also affect the characteristic of dried salted anchovies.

Drying is one of the most affordable traditional fish preservation methods that are commonly used in many developing countries (Solanki, 2020). Drying is the decrease of the water activity to maintain food quality by reducing microbial growth and undesired chemical reaction (Abbas et al., 2009). Research on characteristic drying anchovy was carried out by Subarkah et al. (2013), however, a mathematical model analysis has not been carried out. Drying kinetics describe the process of removing moisture and how to relate the variable process, which is deemed important in the development of a drying model (Gupta and Patil, 2014).

Mathematical modelling has been widely used for the analysis of the drying process. There is limited information available on the drying kinetics of fish (Jain and Pathare, 2007). The use of these mathematic models was considered to be important in choosing appropriate drying conditions for effective drying and to obtain quality dried fish (Adeyeye, 2019). Drying kinetics is an important process that is used to determine and predict 
the drying behaviour of food material as well as to optimize the food drying parameters Vega-Gálvez et al., 2011).

The aim of this work is to study the drying kinetics and determine the most suitable mathematical models of dried salted anchovy processed with three different treatments: boiled salting and drying in the mechanical dryer (BMD), soaked salting and drying in the mechanical dryer (SMD) and boiled salting and drying in the oven (BOD).

\section{Materials and methods}

\subsection{Sample preparation}

Fresh anchovy was obtained from Rejomulyo Fish Market, Semarang City, Central Java. They were taken to the laboratory in a cooling box. The anchovy was washed and drained to reduce the water content.

\subsection{Experimental procedure}

The fresh anchovy was treated with 2 different salting methods, namely soaking (S) in $5 \%$ brine for 30 mins and boiling (B) with $5 \%$ brine for 10 mins. Samples that were given the boiling treatment were then aerated for a while in the open until they cooled slightly. The anchovy samples were then dried using an electric oven (OD) and mechanical dryer (MD) at $40^{\circ} \mathrm{C}$ for $3 \mathrm{hrs}$. There were 3 processing methods studied in this research, namely boiled and dried with the mechanical dryer (BMD), soaked and dried with the mechanical dryer (SMD) and boiled and dried with oven (BOD). The weight loss of the samples was measured during the drying process every $30 \mathrm{mins}$ using an analytical balance. Moisture content was measured every $30 \mathrm{mins}$ using the thermo-gravimetric method to determine the pattern of moisture content reduction.

\subsection{Moisture content (MC)}

Moisture content was determined according to the official methods of analytical chemistry (AOAC, 2019). The percentages moisture content was composed as follow:

MC $(\%)=($ loss in weight on drying $(\mathrm{g}) /$ initial

\subsection{Moisture ratio (MR)}

The moisture content of the drying sample at time $t$ can be transformed to be Moisture Ratio (MR) calculated with the following equation (Rayaguru and Routray, 2012).

$M R=\left(M_{t}-M_{e}\right) /\left(M_{0}-M_{e}\right)$

\subsection{Drying kinetics models}

Non-linear regression analysis was performed using Microsoft Excel. The matching results between experimental data and mathematical models were evaluated by the coefficient of determination $\left(\mathrm{R}^{2}\right)$ and the Standard Error of Estimate (SEE). The best possible matching is those with the greatest $R^{2}$ value and the smallest SEE. Thin-layer drying models can be categorized as theoretical, semi-theoretical and empirical models. Each model is developed based on certain principles (Kashaninejad et al., 2007). The semitheoretical drying model has been developed and becomes a better model that fits the data on drying fish fillets (Konishi et al., 2001; Hadrich et al., 2008; VegaGálvez et al., 2009). Examples of semi-theoretical drying models are the Lewis model, Henderson and Pabis model, Page Model (Adeyeye, 2019).

Henderson and Pabis mathematical model has been used in drying maize, but the inaccuracy and temperature difference is high (Henderson and Pabis, 1961). The use of mathematical model from Lewis is inaccurate because the drying estimate is excessive in the first period and under the estimate for the last period (Bruce, 1985). However, a simplified semi-theoretical model of general series solutions of second law Fick. In the semitheoretical model, the time requirements and the form of the dried material are not taken into (Henderson and Pabis, 1961; Bruce, 1985). The Page mathematical model is a modification of the Lewis model to overcome deficiencies and was successfully used to describe the drying characteristics of various agricultural products account (Doymaz, 2007; Aghbashlo et al., 2009; Doymaz and Ismail, 2011). The equation of mathematical models from Lewis, Page and Henderson Pabis were shown in Table 1.

Table 1. Mathematical models

\begin{tabular}{cl}
\hline Models & \multicolumn{1}{c}{ Equation } \\
\hline \multirow{2}{*}{ Lewis } & MR $=\exp (-\mathrm{kt})$ \\
& $\ln (\mathrm{MR})=-\mathrm{kt}$ \\
\hline \multirow{2}{*}{ Page } & $\mathrm{MR}=\exp \left(-\mathrm{kt}^{\mathrm{n}}\right)$ \\
& $\mathrm{In}(-\ln (\mathrm{MR}))=\ln (\mathrm{k})+\mathrm{nln}(\mathrm{t})$ \\
\hline \multirow{2}{*}{ Henderson and Pabis } & $\mathrm{MR}=\mathrm{a} \exp (-\mathrm{kt})$ \\
& $\mathrm{In} \mathrm{MR}=-\mathrm{kt}+\ln (\mathrm{a})$ \\
\hline
\end{tabular}

MR: Moisture Ratio, k: drying constant, a: coefficient of drying models and $\mathrm{n}$ : exponential coefficient

\subsection{Effectiveness of diffusion}

The effectiveness of diffusion was evaluated with the following equation:

$\mathrm{MR}=\frac{8}{\pi 2} \exp \left(\frac{\text { Deff }}{4 L 2}\right)$ 
Where $D_{\text {eff }}$ is the effective diffusivity $\left(\mathrm{m}^{2} / \mathrm{s}\right)$ and $L$ is half the thickness of the material (m).

Equation 3 can be changed in logarithmic form as follows:

$\operatorname{Ln}(\mathrm{MR})=\ln \frac{8}{\pi 2}-\frac{\text { Deff }}{4 L 2} t$

\section{Results and discussion}

\subsection{Moisture content}

The effect of salting and drying methods on the moisture content of dried salted anchovies is shown in Figure 1. Dried salted anchovies sample treated with SMD, BMD and BOD at 0 mins has a water content of $81.45 \%, 75.71 \%$, and $75.51 \%$. The moisture content of the sample after drying at $40^{\circ} \mathrm{C}$ for $3 \mathrm{hrs}$ became $35.75 \%, 21.26 \%$, and $32.56 \%$ respectively.

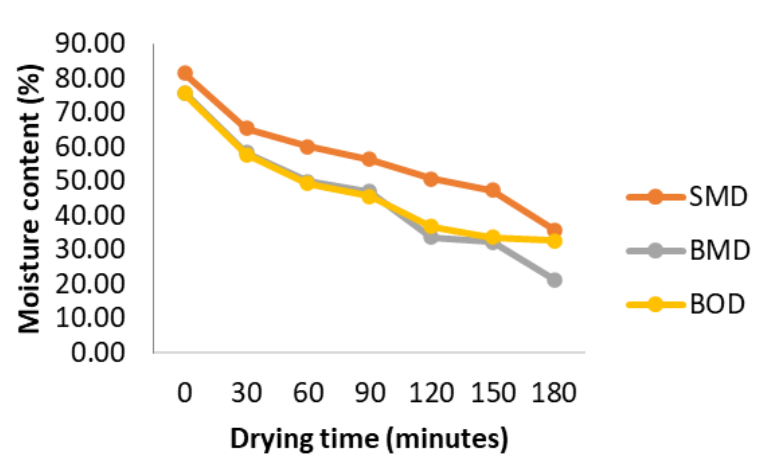

Figure 1. Decrease of moisture content during drying

The largest reduction in water content was found in the BMD treated anchovy. The interaction of boiling in brine and drying reduces moisture content on dried salted anchovy. Drying temperature and drying time affect the moisture content and drying characteristic of anchovy (Subarkah et al., 2013). Moreover, the addition of salt also affected the water content of salted fish. This is due to the salt that is absorbed into the fish meat denaturing the colloidal protein solution resulting in coagulation which causes water to come out of the fish muscle. The decrease in water content is also caused by the moisture transfer from the material's surface to the drying air that takes place by the convection process. A certain amount of steam is needed. Hence, the mass of the water inside the fish can be evaporated (Izdiharrudin et al., 2019).

\subsection{Weight loss}

Figure 2 show the initial weight of the fresh anchovy before the drying process for SMD, BMD and BOD treatments were 7.78, 7.71, and $7.016 \mathrm{~g}$ respectively.

Weight loss of fish is indicated by the reduction of fish weight. Fish weight reduction occurs during the salting and drying process. The treatment that gave the biggest reduction in fish weight was the salting method by boiling in brine and drying method with mechanical dryer. Water content released from the fish when the osmotic process occurs during salting. Air circulation speeds up the drying process in the mechanical dryer where warm air reached the fish in every rack of the drying chamber (Karim et al., 2018).

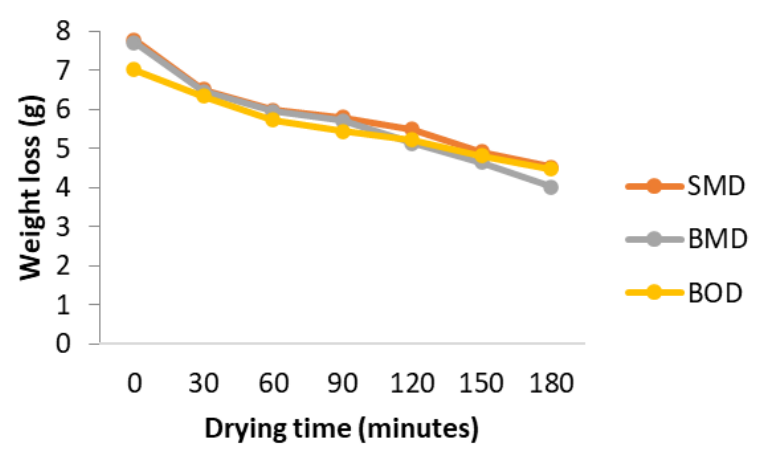

Figure 2. Weight loss during drying

\subsection{Drying kinetics}

\subsubsection{Drying rate}

Figure 3 shows how the drying rate decreased along with time. Because the longer the drying time, the less water evaporates during the process. The highest drying rate occurs in the mechanical dryer and soaking methods (SMD). The high velocity of airflow affects the drying rate (Putra and Ajiwiguna, 2017).

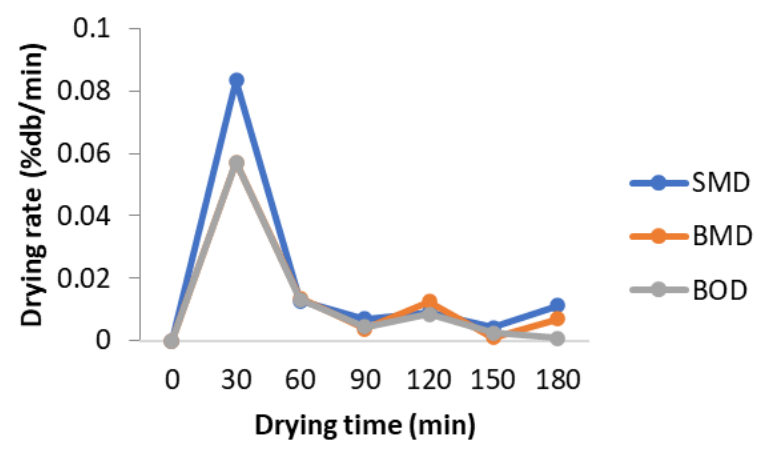

Figure 3. Drying rate

At the beginning of the drying process, the rate of drying runs very fast, then slows down until the drying process ends. These are related to the presence of free water and bound water in the fish. The amount of free water content at the beginning of the drying process is still high, it is easy to release. While at the end of the process, drying has begun to release the bound water which has lower vapour pressure than the pressure of free water vapour at the same temperature. The drying time of salted dried anchovy was accelerated with the osmosis process as a pre-treatment prior to air drying (Shalini et al., 2017).

\subsubsection{Moisture ratio}

Figure 4 shows the moisture ratio of the dried salted anchovies plotted versus drying time. The pattern of 
decreasing moisture ratio is in line with the pattern of decreasing moisture content during the drying process. The moisture ratio was calculated based on the changes of moisture content in a material (Jain and Pathare, 2007). The moisture ratio was then analyzed with Microsoft Excel to determine the mathematical models of drying (Topuz and Hamzacebi, 2010).

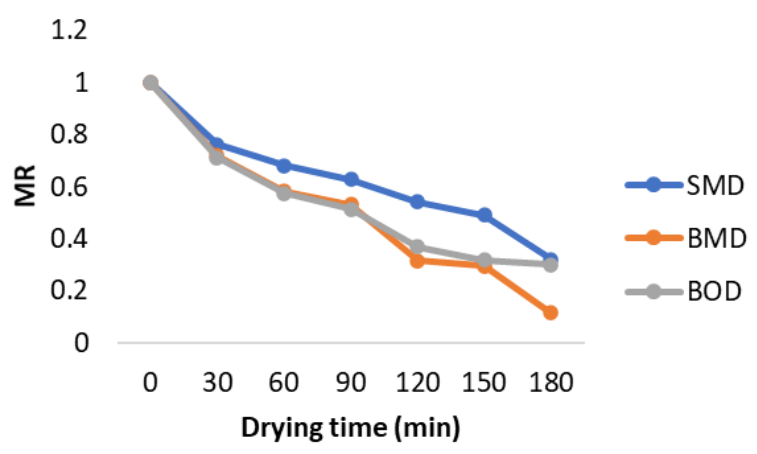

Figure 4. Moisture Ratio (MR) of anchovy during drying

\subsubsection{Drying models}

Models and drying constants of dried salted anchovy are shown in Table 2. Moisture ratios were analysed by linear regression using Microsoft Excel to determine the value of each drying constant in each model. The drying constant $(a, n)$ is used to calculate the MR value of each model. $\mathrm{R}^{2}$ (coefficient of determination) and SEE (standard error of estimate) values were used to determine the most suitable models of drying. The highest $\mathrm{R}^{2}$ value is found on the page model on the BMD treatment, which is equal to 0.9925 with a value of 0.023643293 . This value shows that the page model is the most suitable model for dried anchovies because the MR value of the model is close to the MR value of the research results. Drying kinetic models does not take into account the effect of interaction by parameters other than the time of drying (Khazaei and Daneshmandi, 2007). Various fruit and vegetable studies explain that the Page model illustrates the appropriate research curve (TaheriGaravand et al., 2011). Page models are more effective to use in equations with more time in calculating data (Kashaninejad et al., 2007; Yadollahinia et al., 2008).
Based on Table 2, the page model is the most suitable model for dried salted anchovy with the model equation $\mathrm{MR}=\exp \left(-\mathrm{kt}^{\mathrm{n}}\right)$.

\subsubsection{Effective diffusivity}

The effective diffusivity value in drying dried anchovy can be obtained by plotting Ln MR versus time (t) as shown in Figure 5. The plotting results are then used to find the slope and the value of the curve. The slope is then used to find the effective diffusivity $\left(D_{\text {eff }}\right)$ with the result shown in Table 3.

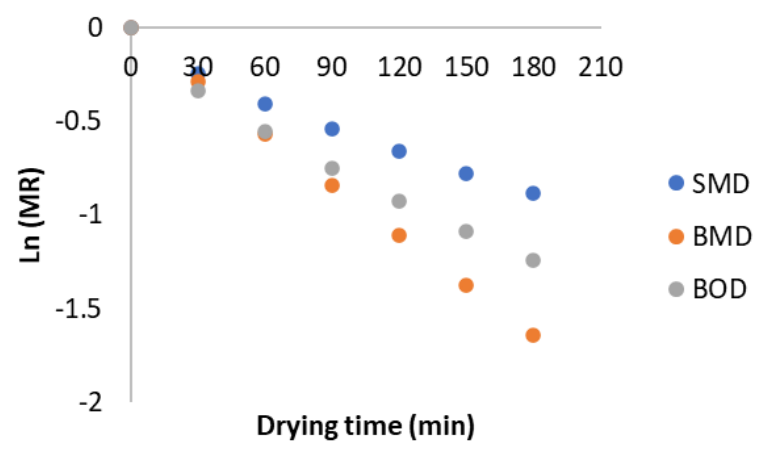

Figure 5. Relationship between Ln MR and drying time

Table 3 shows the highest value for dried salted anchovy on BMD treatment. Different methods of the drying process could have a different effect on the effective diffusivity of the drying material (Hashemi et al., 2009). Measurement of effective diffusivity, which is a parameter used in predicting moisture transfer, and advanced measurement of moisture profiles to quantify and validate predictive models (Srikiatden and Roberts, 2007). Variety, heat sorption within the food and composition of the material is another factor that affects effective diffusivity (Kashaninejad et al., 2007).

Table 3. Effective diffusivity of dry salted anchovy

\begin{tabular}{cc}
\hline Methods & Deff $\left(\mathrm{m}^{2} / \mathrm{s}\right)$ \\
\hline SMD & $1,28067 \times 10^{-10}$ \\
BMD & $2,46685 \times 10^{-10}$ \\
BOD & $1,80245 \times 10^{-10}$ \\
\hline
\end{tabular}

\section{Conclusion}

Salting anchovy with boiling in brine and drying in a

Table 2. Models and drying constants of dried salted anchovy

\begin{tabular}{ccccccc}
\hline Model & Methods & $\mathrm{k}$ & $\mathrm{a}$ & $\mathrm{n}$ & $\mathrm{R}^{2}$ & $\mathrm{SEE}$ \\
\hline \multirow{3}{*}{ Lewis } & SMD & 0.0056 & & & 0.9535 & 0.0540808 \\
& BMD & 0.0099 & & & 0.9624 & 0.06380212 \\
& BOD & 0.0075 & & & 0.9751 & 0.04616903 \\
\hline \multirow{2}{*}{$\begin{array}{c}\text { Henderson } \\
\text { and Pabis }\end{array}$} & SMD & 0.0054 & 0.97238837 & & 0.9536 & 0.05139583 \\
& BMD & 0.0105 & 1.0907876 & & 0.9596 & 0.07364771 \\
& BOD & 0.0067 & 0.90946388 & & 0.9704 & 0.04334106 \\
\hline \multirow{4}{*}{ Page } & SMD & 0.0211 & & 0.7193 & 0.9552 & 0.04762324 \\
& BMD & 0.0275 & & 0.7339 & 0.9925 & 0.02364329 \\
& BOD & 0.0105 & & 0.9736 & 0.9645 & 0.05997941 \\
\hline
\end{tabular}


mechanical dryer (BMD) gave the highest drying rate. Page model is the most suitable mathematical model due to the highest $R^{2}$ value and lower SEE average value. Effective diffusivity value of SMD, BMD and BOD was $1,28067 \times 10^{-10}, \quad 2,46685 \times 10^{-10}$ and $1,80245 \times 10^{-10}$ respectively. This method contributes to the improvement of the drying and salting method to achieve a better quality of dried salted anchovy.

\section{Conflict of interest}

The authors declare no conflict of interest.

\section{References}

Abbas, K.A., Saleh, A.M., Mohamed, A. and Lasekan, O. (2009). The Relationship Between Water Activity and Fish Spoilage During Cold Storage: A review. Journal of Food Agriculture and Environment, 7(3/4), 86-90.

Adeyeye, S.A.O. (2019). An Overview of Fish Drying Kinetics. Nutrition and Food Science, 49(5), 886902. https://doi.org/10.1108/NFS-10-2018-0296

Aghbashlo, M., Kianmehr, M.H. and SamimiAkhijahani, H.A.D.I. (2009). Evaluation of Thin Layer Drying Models for Describing Drying Kinetics of Barberries (Barberries vulgaris). Journal of Food Process Engineering, 32(2), 278-293. https://doi.org/10.1111/j.1745-4530.2007.00216.x

AOAC. (2019). Official Methods of Analysis. $21^{\text {st }}$ ed. USA: AOAC International.

Bruce, D.M. (1985). Exposed-Layer Barley Drying: Three Models Fitted to New Data up to $150^{\circ} \mathrm{C}$. Journal of Agricultural Engineering Research, 32(4), 337-348. https:// doi.org/10.1016/0021-8634(85)90098-8

Chabbouh, M., Hajji, W., Hadj Ahmed, S.B., Farhat, A., Bellagha, S. and Sahli, A. (2011). Combined Effects of Osmotic Dehydration and Convective Air Drying on Kaddid Meats: Kinetics and Quality. Drying Technology, 29(13), 1571-1579. https:// doi.org/10.1080/07373937.2011.582973

Doymaz, I. (2007). Air-Drying Characteristics of Tomatoes. Journal of Food Engineering, 78(4), 1291 $-1297$. https://doi.org/10.1016/ j.jfoodeng.2005.12.047

Doymaz, I. and İsmail, O. (2011). Drying Characteristics of Sweet Cherry. Food and Bioproducts Processing, 89(1), 31-38. https://doi.org/10.1016/ j.fbp.2010.03.006

Gupta, S.V. and Patil, B.N. (2014). Convective Drying of Osmo-Dehydrated Sapota Slice. International Journal of Agricultural and Food Science, 5(3), 219-
226.

Hadrich, B., Boudhrioua, N. and Kechaou, N. (2008). Drying of Tunisian Sardine (Sardinella aurita) Experimental Study and Three-Dimensional Transfer Modeling of Drying Kinetics. Journal of Food Engineering, 84(1), 92-100. https://doi.org/10.1016/ j.jfoodeng.2007.04.025

Hashemi, G., Mowla, D. and Kazemeini, M. (2009). Moisture Diffusivity and Shrinkage of Broad Beans During Bulk Drying in an Inert Medium Fluidized Bed Dryer Assisted by Dielectric Heating. Journal of Food Engineering, 92(3), 331-338. https:// doi.org/10.1016/j.jfoodeng.2008.12.004

Henderson, S.M. and Pabis, S. (1961). Grain Drying Theory (I) Temperature Effect on Drying Coefficient. Journal of Agricultural Engineering Research, 6(3), 169-174.

Izdiharrudin, M.F., Hantoro, R. and Hepriyadi, S.U. (2019). Heat Transfer Analysis of Solar Fish Drying Machine on the Effects of Fish Mass and Blower Speed Variations. American Journal of Modern Energy, 5(2), 19-22. https://doi.org/10.11648/ j.ajme. 20190502.13

Jain, D. and Pathare, P.B. (2007). Study the Drying Kinetics of Open Sun Drying of Fish. Journal of Food Engineering, 78(4), 1315-1319. https:// doi.org/10.1016/j.jfoodeng.2005.12.044

Karim, E., Haque, M.M. and Hoq, M.E. (2018). Improvement of Dried Fish Products Through Using a Mechanical Fish Dryer. Bangladesh Journal Fisheries Research, 17(1-2), 91-99.

Kashaninejad, M., Mortazavi, A., Safekordi, A. and Tabil, L.G. (2007). Thin-Layer Drying Characteristics and Modeling of Pistachio Nuts. Journal of Food Engineering, 78(1), 98-108. https://doi.org/10.1016/j.jfoodeng.2005.09.007

Khazaei, J. and Daneshmandi, S. (2007). Modeling of Thin-Layer Drying Kinetics of Sesame Seeds: Mathematical and Neural Networks Modeling. International Agrophysics, 21(4), 335348.

Konishi, Y., Horiuchi, J.I. and Kobayashi, M. (2001). Dynamic Evaluation of The Dehydration Response Curves of Foods Characterized by a Poultice-up Process Using a Fish-Paste Sausage. II. A New Tank Model for a Computer Simulation. Drying Technology, 19(7), 1271-1285. https:// doi.org/10.1081/DRT-100105288

Kumar, G.P., Xavier, K.M., Nayak, B.B., Kumar, H.S., Venkateshwarlu, G. and Balange, A.K. (2017). Effect of Different Drying Methods on The Quality Characteristics

Pangasius 
hypophthalmus. International Journal Current Microbiology Applied Sciences, 6(10), 184-195. https://doi.org/10.20546/ijcmas.2017.610.024

Martínez-Alvarez, O. and Gómez-Guillén, C. (2013). Influence of Mono-and Divalent Salts on Water Loss and Properties of Dry Salted Cod Fillets. LWT-Food Science and Technology, 53(2), 387-394. https:// doi.org/10.1016/j.lwt.2013.04.013

Mujaffar, S. and Sankat, C.K. (2005). The Air Drying Behaviour of Shark Fillets. Canadian Biosystems Engineering, 47(3), 11-13.

Putra, R.N. and Ajiwiguna, T.A. (2017). Influence of Air Temperature and Velocity for Drying Process. Procedia Engineering, 170, 516-519. https://doi.org/10.1016/j.proeng.2017.03.082

Rayaguru, K. and Routray, W. (2012). Mathematical Modeling of Thin Layer Drying Kinetics of Stone Apple Slices. International Food Research Journal, 19(4), 1503-1510.

Shalini, J.S., Samsher, S.C. and Vivak Kumar, N. (2017). Effect of Moisture Content and Drying Rate on Dried Aonla Shreds During Ambient Storage. International Journal of Chemical Studies, 5(4), 362-366.

Siriskar, D.A., Khedkar, G.D. and Lior, D. (2013). Production of Salted and Pressed Anchovies (Stolephorus sp.) and It's Quality Evaluation During Storage. Journal of Food Science and Technology, 50(6), 1172-1178. https:// doi.org/10.1007/s13197-011-0450-9

Solanki, J.B. (2020). Different Types of Fish Drying Methods in Gujarat. International Journal of Fisheries and Aquatic Studies, 8(1), 129-131.

Srikiatden, J. and Roberts, J.S. (2007). Moisture Transfer in Solid Food Materials: A Review of Mechanisms, Models, and Measurements. International Journal of Food Properties, 10(4), 739-777. https:// doi.org/10.1080/10942910601161672

Subarkah, R., Abdurachim, Hendrarsakti, J. and Belyamin. (2013). Drying Characteristic of Anchovy Fish. Journal of Food Science and Engineering, 3 (2), 87-93.

Taheri-Garavand, A., Rafiee, S. and Keyhani, A. (2011). Study on Effective Moisture Diffusivity, Activation Energy and Mathematical Modeling of Thin Layer Drying Kinetics of Bell Pepper. Australian Journal of Crop Science, 5(2), 128-131.

Topuz, A. and Hamzacebi, C. (2010). Moisture Ratio Prediction in Drying Process of Agricultural Products: A New Correlation Model. Applied Engineering in Agriculture, 26(6), 1005-1011. https://doi.org/10.13031/2013.35901
Vega-Gálvez, A., Andrés, A., Gonzalez, E., NotteCuello, E., Chacana, M. and Lemus-Mondaca, R. (2009). Mathematical Modelling on The Drying Process of Yellow Squat Lobster (Cervimunida jhoni) Fishery Waste for Animal Feed. Animal Feed Science and Technology, 151(3-4), 268-279. https:// doi.org/10.1016/j.anifeedsci.2009.01.003

Vega-Gálvez, A., Miranda, M., Clavería, R., Quispe, I., Vergara, J., Uribe, E. and Di Scala, K. (2011). Effect of Air Temperature on Drying Kinetics and Quality Characteristics of Osmo-Treated Jumbo Squid (Dosidicus gigas). Food Science and Technology, 44 (1), 16-23. https://doi.org/10.1016/j.lwt.2010.06.012

Yadollahinia, A.R., Omid, M. and Rafiee, S. (2008). Design and fabrication of experimental dryer for studying agricultural products. International Journal of Agriculture and Biology, 10(1), 61-65. 